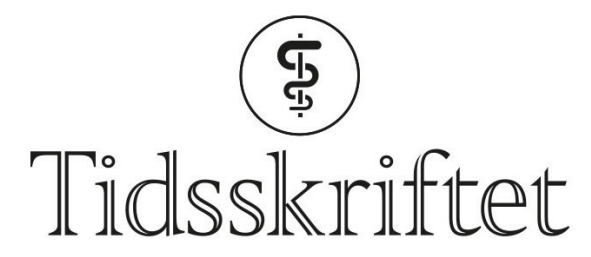

DEN NORSKE LEGEFORENING

\title{
Medisinsk historie som glede og fjell
}

ESSAY

\section{AINA SCHIØTZ}

E-post:aina.schiotz@uib.no

Institutt for global helse og samfunnsmedisin

Universitetet i Bergen

Aina Schiøtz (f. 1947) er professor emerita i medisinsk historie.

Forfatter har fylt ut ICMJE-skjemaet og oppgir ingen interessekonflikter.

Medisinsk historie er et spennende, meningsgivende og nødvendig fag. Derfor publiserer også Tidsskriftet medisinhistoriske artikler. Med utgangspunkt i mine erfaringer som medisinhistoriker ønsker jeg å gi et innblikk i fagfeltets skiftende tradisjoner. Jeg søker også å belyse hvilket utbytte leger kan ha av å kjenne sin historie, og hvordan leger og historikere kan samarbeide i å utforske fagets og profesjonens røtter og fremvekst.

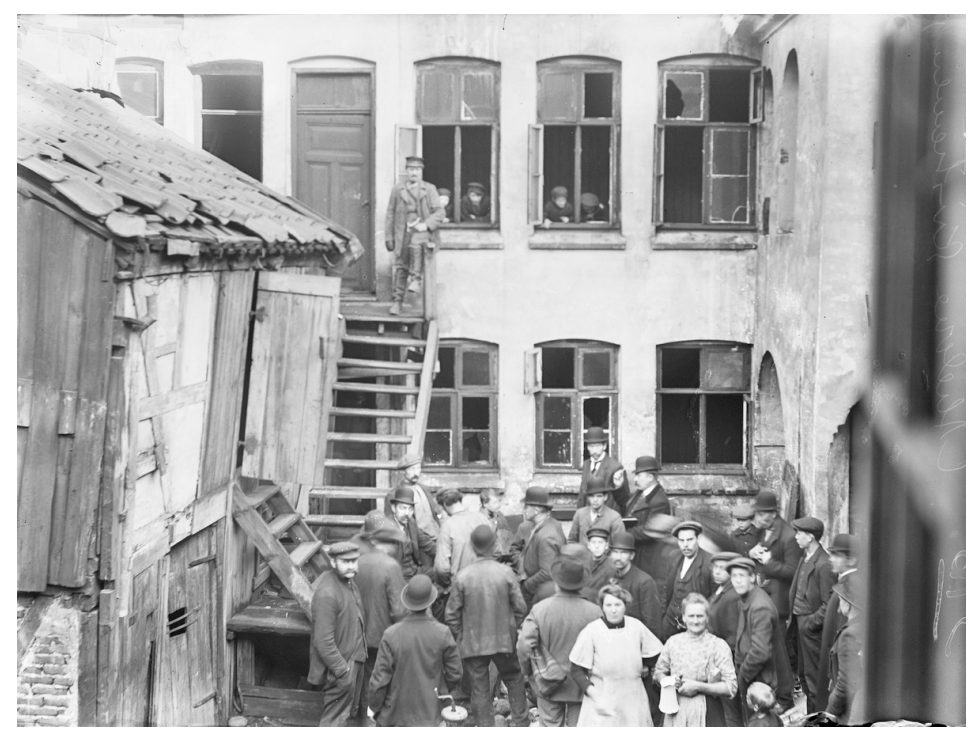

I annen halvdel av 180o-tallet var bydelene Fjerdingen, Vika og Vaterland $i$ Kristiania tilholdssted for byens bordeller. Her fra «Abelone-gården" på Vaterland, som både var skjenkested og bordell. Stedet var også kjent for å drive bondefangeri der kunden risikerte å bli ranet. Foto:Johannes Holmsen / Oslo Museum / Byhistorisk samling (CC BY-SA)

I løpet av noen septemberuker i 1992 hadde jeg en opplevelse som pekte mot et lykkelig vendepunkt i livet. Jeg var ansatt ved Norsk Folkemuseum i en administrativ stilling, men hadde fått permisjon for å skrive om Marie Spångberg (1865-1942), gift Spångberg Holth. Som første kvinne i Norge avla hun medisinsk embetseksamen i 1893.

Legeforeningens likestillingsutvalg ved Berit Schei og Tidsskriftets redaksjon ville markere hundreårsjubileet for denne begivenheten og hadde bedt meg skrive. Jeg hadde historie 
hovedfag fra vel 15 år tilbake, og i årene etter eksamen lurte jeg stadig på om jeg hadde valgt feil da jeg sto på terskelen til yrkeslivet. I høstukene i 1992 skulle jeg igjen få smaken på forskning. I bestrebelsene med å samle data om Spångberg, fortolke og forstå hadde jeg med meg tre grunnregler fra historiefaget: kontekstualisering, kildekritikk og etterrettelighet.

Det kom mye ut av arbeidet, flere artikler og mange foredrag. Det første av det siste skulle finne sted ved Regionsykehuset i Trondheim, i dag St. Olavs hospital, 8. mars 1993. Ville det komme noen? Auditoriet var stappfullt av kvinnelige leger fra fjern og nær. Som svamper sugde de til seg kunnskap om egen profesjon og den kampen deres medsøstre og støttespillere hadde ført for å gi dem en plass i den.

Det ble en sterk opplevelse og en grundig manifestasjon av historiefagets berettigelse. For meg ble veien videre staket ut høsten 1992. Jeg søkte meg til forskningen og er forblitt der.

\section{Skiftende fagtradisjoner}

Jeg tok min utdanning i 1970-årene, og hovedoppgavens tema var prostitusjonen i bohemtidens Kristiania $(1,2)$. Jeg ble skolert i den sosialhistoriske fagtradisjonen som vokste frem dette tiåret. Historiefagets konsentrasjon om de politiske og økonomiske elitene og de store begivenhetene ble utfordret. Vekten ble lagt på studiet av sosiale grupper, og særlig på de underprivilegerte. Fattige, syke, barn, kvinner, undertrykte og utstøtte ble historiske aktører og fortolket i en sosial sammenheng.

Også maktperspektivet sto sterkt. Forholdet mellom de styrte og de styrende ble problematisert, og de med makt og posisjon ble gransket fra en tosidig synsvinkel. Ikke oppsiktsvekkende føyet interessen for det sosialhistoriske seg inn i en bredere politisk bevegelse, nærmere bestemt den venstreradikale sekstiåttergenerasjonens autoritetsopprør og kampen for demokratisering og desentralisering av makt og beslutninger. Metoder, teorier og analyseredskaper ble hentet fra sosiologien og andre samfunnsvitenskaper (3-5).

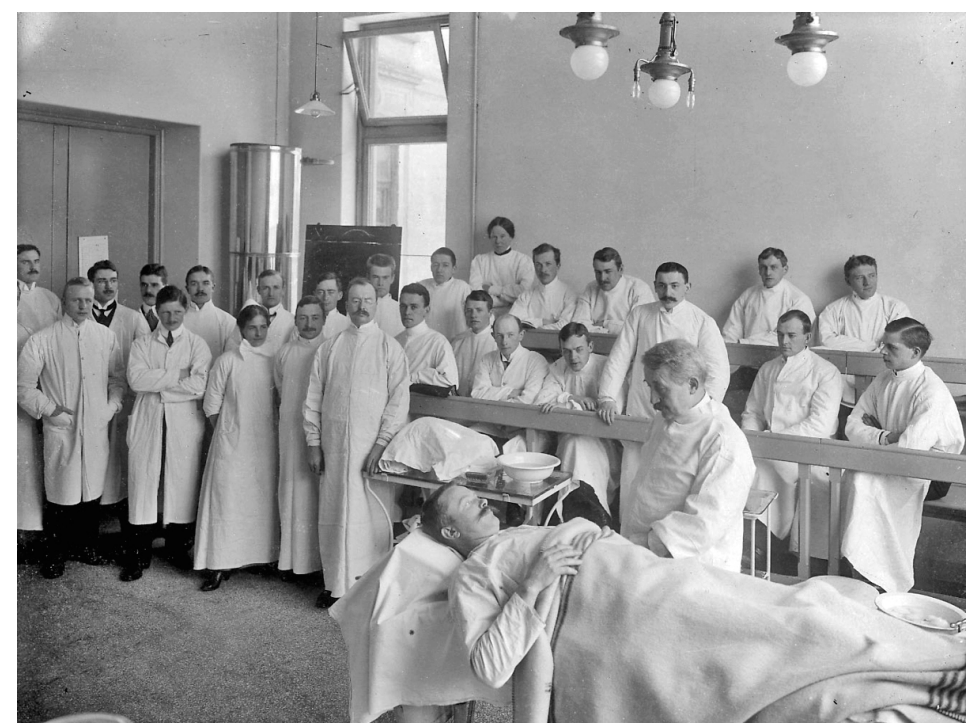

Undervisning ved Rikshospitalet under ledelse av professor i kirurgi Hagbarth Strøm ca. 1910. Foto: Rude \& Hilfling/Oslo Museum / Byhistorisk samling (CC BY-SA)

I mitt hovedfagsarbeid var politilegens protokoller hovedkilden. Her fikk jeg innsikt i ulike medisinhistoriske problemstillinger, som kjønnssykdommer, behandlingsmetoder, utbredelse og dødelighet, spedbarnsdødelighet og helselovgivning - og ikke minst fikk jeg innsikt i legestandens holdninger og forestillinger om kvinner generelt og de prostituerte spesielt.

Jeg benyttet både en kvantitativ og en kvalitativ tilnærming (1, 2). Av mine hovedfunn var hvor sterkt prostitusjonen og kjønnssykdommene og deres utbredelse ble bestemt ut fra $\emptyset$ konomiske forhold: Jo bedre tider, jo færre prostituerte kvinner, men desto større utbredelse av kjønnssykdommer. For det første pekte dette mot at flere menn hadde $\emptyset$ konomi til å kjøpe seksuelle tjenester og at relativt få kvinner betjente mange kunder, for 
det andre at $ø$ konomisk nød skaper prostitusjon.

Et annet funn var hvor sterkt legestanden forsvarte den offentlige prostitusjonen - det såkalte reglementeringssystemet, som eksisterte i perioden $1840-88$. Foruten offentlige bordeller (de siste stengt i 1884) innebar dette tvungen ukentlig kontroll hos politilegen av de registrerte kvinnene (jf. C. Krohgs maleri Albertine i politilegens ventevcerelse, 1886-87). Hindret man prostitusjonen, var det som å stoppe til et kloakkutløp, som medisinaldirektør Ludvig Dahl (1826-9o) uttrykte det: «... hvis stinkende Indhold strax søger andre Udveie og da gjennem en Mængde uundgaaelig Utætheder, hvis Omgivelser de inficerer» (6, s. 75).

At det fra langt tilbake i historien var en retning i historiefaget som het medisinens historie, var ukjent for meg på dette tidspunktet. Først senere ble jeg oppmerksom på at denne subdisiplinen hadde dype røtter. Helt fra tidlig på 18oo-tallet ble det for eksempel $\mathrm{i}$ tysktalende stater undervist i faget ved de medisinske fakultetene (7). Det var profesjonens egne som sto for undervisningen, og det var gjerne fremskrittshistorien som ble fremhevet og feiret, men ikke bare. The Whiggish history of Medicine er den blitt kalt.

Begrepet «Whig history», som slett ikke er begrenset til medisinen, ble lansert i 1931 av den britiske historikeren Herbert Butterfield (1900-79). I sin klassiske bok The Whig Interpretation of History skrev han følgende i forordet: "What is discussed is the tendency in many historians to [...] emphasize certain principles of progress in the past and to produce a story which is the ratification if not the glorification of the present» $(8$, s. 2$)$.

Den svenske idéhistorikeren Karin Johannisson (1944-2016) hevdet at innenfor medisinen er tradisjonen blitt karakterisert som fagets «selvforherligende livshistorie», som har forsømt det sosiale og kulturelle rommet der det medisinske verdensbildet formuleres, gestaltes og praktiseres (9, s. 8). I 2017 kan vi slå fast at dette er en posisjon som stort sett er forlatt av både medisinere og faghistorikere som beskjeftiger seg med medisinsk historie.

I 1980- og 90-årene ble det formet en fagtradisjon som utfordret den sosialhistoriske tilnærmingen. «Den nye kulturhistorien» fikk innpass blant medisinhistorikerne, og det er en retning som fortsatt står sentralt $(3,10)$. Teorier og metoder blir hentet fra en rekke andre fag, som antropologi, filosofi, litteraturvitenskap, språkvitenskap og kjønnsforskning. Oppmerksomheten blir rettet mot ideologier og kulturelle aspekter ved medisin og helse og hvordan skiftende ideologier og kulturelle særtrekk har virket inn på og formet forståelsen av menneskelivets ulike sider.

Søken etter mening er viktig - hvilke konnotasjoner og assosiasjoner knyttes for eksempel til ulike diagnoser. Forskerne stiller videre spørsmål ved normalitetsbegrepet og sykdomsbegrepet. Hva er normalt? Hva er sykdom? Hvordan har forståelsen av og grensene for hva som er friskt og hva som er sykt endret seg over tid? Hvem har definert innhold og grensesetting? Hvilke konsekvenser har rådende oppfatninger hatt?

Forskerne analyserer språk og tegn og deres evne til å skape mentale forestillinger og bilder - som så kan manifesteres i praktisk handling. Mest av alt synliggjør de hvor tett medisinen og kulturen er filtret sammen. Eksempelvis kan de spørre om hvordan medisinen har formet kropps- og skjønnhetsidealene og om hva den til ulike tider har tillagt kvinner og menn av anatomiske, fysiologiske og mentale særtrekk $(11,12)$.

Retningen, «den nye kulturhistorien», har vært kritisert for å være lite samfunnskritisk og for å ha fjernet seg fra medisinen selv. Blant de krasseste kritikerne finner vi den britiske medisinhistorikeren Roger Cooter, som hevder at impulsene fra kulturhistorien og den metodologiske relativismen har ført historikerne bort fra å være samfunnsbevisste, relevante og hardtslående. Videre har han påpekt at «kulturhistorien» har vært uklar og fremmedgjørende for helsefeltets egne aktører (13).

Andre, som den svensk-danske medisinhistorikeren Thomas Söderqvist, stilte for noen år tilbake spørsmålet om historikere og andre ikke-medisinere er i ferd med å overta medisinhistorien fullt og helt. Sakkunnskapen forsvant i historikernes fremstillinger, hevdet han. (Söderqvist i innledningsforedrag til medisinskhistorisk seminar ved 
Medicinsk Museion, København, juni 2001. Forfatteren har vært i kontakt med Söderqvist, som fortsatt står inne for det han sa.)

Muligens som en reaksjon på slike «advarsler» skimter vi ved overgangen til 2ooo-tallet en gradvis vending i tyngdepunkt - nå med mer vekt på vitenskapshistorie, innbefattet medisinsk teknologi (4). Slik kunne man i større grad legitimere og vinne gehør for forskningen i medisinhistorikernes fremste målgruppe - legene. For vitenskapshistorien knytter utvilsomt bånd mellom fortid og nåtid i et raskt skiftende samfunn der vi står overfor store etiske utfordringer, avgjørende helsepolitiske veivalg og en stadig mer komplisert teknologi som det knapt er mulig å få innsikt i, selv for fagfolk.

I motsetning til den tidlige medisinhistorien, der oppmerksomheten gjerne ble rettet mot de store gjennombruddene i faget, konsentrerer man seg nå mer om selve kunnskapsproduksjonen og betingelsene for gjennombruddene. Det gjelder også fadeser, feil og utelatelser (14).

Men også etiske overtramp må tilføyes. En analytisk og kritisk tilnærming er viktig. Medisinhistorikerne Christoph Gradmanns studier om Robert Koch og bakteriologiens gjennombrudd og Lise Kvandes arbeider om innføringen og bruken av ultralyd i Norge representerer ulike sider ved vår tids vitenskapshistorie $(15,16)$, mens den amerikanske historikeren Susan Reverbys arbeider om utprøvning av penicillin mot syfilis i Guatemala i regi av det amerikanske Public Health Service synliggjør og diskuterer etiske problemstillinger. I prosjektet ble forsøkspersonene - fanger, soldater og psykiatriske pasienter - inokulert med syfilitisk materiale, uten at de selv hadde gitt samtykke. Konsekvensene var katastrofale (5, s. 90-91, 17).

Hvor står vi i dag? Den første og de to sistnevnte forskningsretningene er alle representert i forskerkollegiet, i større studier finner vi gjerne en kombinasjon (5). De siste årenes konferanseprogrammer fra The American Association for the History of Medicine gir et innblikk i hvilket vell av temaer som blir problematisert og hvilke teoretiske og metodiske tilganger som blir benyttet. Medisinhistorikere er eklektikere, de henter inspirasjon og redskaper der de best er å hente.

\section{Trygghet, glede og nytte}

Hvorfor har mange leger utbytte av å forske og lese om sitt fag og sin profesjons historie? Hvorfor publiserer Tidsskriftet stadig artikler om medisinsk historie? Er det fordi vi i historien, i det forgangne, finner noe å holde fast i? Som et fjell, noe som ikke flytter seg en tomme, som vi kan legge pannen inntil, som kjøler oss - slik lyrikeren Rolf Jacobsen (1907-94) så vakkert formulerer det i diktet Mere fjell (18). I et fag og en verden i voldsom forandring trenger vi så visst noe fast å legge pannen inntil.

Dette er utvilsomt et motiv, men det finnes flere: Ren og skjær nysgjerrighet og glede, vil enkelte si, og viser til gleden som underholdning og gleden ved å se sammenhenger og forstå - og dermed også til medisinhistoriens egenverdi. Andre trekker frem historiens identitetsskapende rolle og hevder at historisk kunnskap fremmer fellesskap og samhold i legekollektivet. Atter andre vil bruke historien instrumentelt, i første rekke som en kunnskapsbase for faglig og/eller politisk argumentasjon og debatt (19, 20).

Men mest av alt argumenteres det med at historisk kunnskap er viktig for å kunne forstå hvilke forutsetninger og tradisjoner våre liv og vårt samfunn hviler på. Først da vil vi kunne stake opp en vei fremover som er «bærekraftig». Jo bedre du kjenner fortiden, desto bedre forberedt er du i møte med fremtiden, som den amerikanske presidenten Theodore Roosevelt (1858-1919) skal ha uttalt. Rett nok kan vi aldri kopiere historien, men å fatte beslutninger krever refleksjon og historisk kunnskap, og bevissthet kan tjene denne refleksjonen.

Endelig er det dem som hevder at historisk kunnskap spiller en allmenndannende rolle. For medisinerne vil den spesielt bidra til å utdanne og forme reflekterte og ansvarlige leger, 
leger med en rolle- og selvforståelse som gjør dem i stand til å møte sine pasienter og utføre sitt samfunnsoppdrag på en god måte.

Medisinsk historie er et spennende fag, et meningsgivende fag, et nødvendig fag. Jeg elsker mitt fag. Men jeg hadde aldri kunnet forske i det, forstå det og formidle det uten utstrakt hjelp og samarbeid med medisinere og andre fagfolk innen helsefeltet. Det har vært avgjørende for mitt faglige arbeid.

Så kan vi spørre om vi historikere er blitt for spesialiserte og eksklusive. Skyver vi de "glade amatører» blant medisinerne og andre helsearbeidere fra oss ved å legge for strenge historiefaglige kriterier til grunn i vurderingen av deres arbeider? Utsetter vi disse arbeidene for grusom slakt? Kan vi ikke dermed bidra til å frata helseprofesjonene interessen for sine fags historiske røtter? I så fall vil mye gå tapt.

Medisin- og helsehistorien trenger deres ekspertise og deres «internalistiske» blikk. Uten deres bidrag - i form av selvstendige arbeider og/eller innspill - vil sentrale felt innen profesjonenes, fagenes og vitenskapens historie forbli skjult for ettertiden. Uten dem står vi i fare for å produsere forskning kun for forskningens skyld.

\section{Å lære av hverandre - indre og ytre blikk}

Hva er karakterisk for det indre og det ytre blikket på medisinhistorien? La meg ta den epidemiske sykdommen kolera som eksempel og rendyrke de ulike perspektivene (21). Det var en sykdom som herjet stygt i Norge fra 1830-årene og et par tiår fremover. Medisineren har mer enn noen forutsetninger for å kunne belyse fortidens diagnosesetting og behandlingsregimer, men han er lite bevisst sin posisjon som nåtidsmenneske og står i fare for å bedømme diagnostisering og behandling ut fra den kunnskap vi i dag besitter.

Videre er epidemiologen interessant. Han søker å kartlegge smittekilder, morbiditet og mortalitet og har kunnskaper til å kunne vurdere holdbarheten i fortidens diagnostiserings- og klassifiseringskriterier.

Medisineren vil etterspore hvilke forebyggende tiltak som ble satt i verk for å hindre spredning, og spørre om profesjonens engasjement på feltet. Han er dessuten opptatt av å belyse de medisinske gjennombruddene, men er lite eller slett ikke interessert i finne ut av sykdommens betydning for pasientene, for de pårørende og for samfunnet i stort (22).

Ikke sjelden tillegges legene mer eller mindre rettmessig æren for at forholdene er blitt bedre eller for at sykdommen er blitt utryddet eller stoppet. Trekkes fadeser og skandaler frem, knyttes de gjerne til konflikter mellom store vitenskapsmenn. Eller skylden legges på utenforstående aktører eller ses i lys av strukturelle og/eller kulturelle forhold i samfunnet.

Hva med historikeren og det ytre blikket? Historikeren har knapt forutsetninger til å kunne vurdere behandlingsregimer, men vil som medisineren spørre om sykdommens opprinnelse, utbredelse og dødelighet. Hun er imidlertid mest opptatt av konteksten og vil orientere seg om hva slags samfunn som ble rammet - politisk, ideologisk, økonomisk og sosialt. Dernest kan hun gå inn på demografiske forhold og spørre om epidemiens betydning for befolkningssammensetningen på kort og på lang sikt. Videre er det naturlig å finne ut av hvilke politiske, økonomiske, sosiale og kulturelle konsekvenser sykdommen fikk.

De funn hun gjør og de svar hun gir, er som regel avhengig av hvilken vinkling hun legger vekt på. Offentlige tiltak med tanke på forebygging og regulering av borgernes atferd, er også interessant. Videre er helselovgivning, lovenes forarbeider og deres virkning et viktig anliggende.

Historikeren er dessuten kritisk til de kildene hun benytter og spør hvem som produserte dem og for hvilket formål. Én kilde er ingen kilde, har historikeren fått innprentet. Et fenomen må belyses fra flere sider, fra uavhengige og ulike typer kilder. Dette er viktig for både å forklare og å forstå et fenomen i sin samtid. 
På den annen side er historikeren nærmest blottet for kunnskap om diagnostiske metoder og om kroppens biologiske prosesser og anatomiske strukturer og vet lite eller ingenting om de patologiske prosessene. Hun har dessuten liten eller ingen innsikt i medisinsktekniske behandlingsmetoder, medisinsk terminologi og kultur. Slik kommer hun lett i skade for å feilbedømme behandlingsopplegg, en sykdoms karakter og betydning og legenes bidrag i sykdomsbekjempelsen.

Historikere generelt mangler vesentlig innsikt i medisinens mange sider, men har mye å gi i form av kunnskap om hvordan vi skal gå frem når vi vil forske og skrive om det fortidige: Om hvordan vi analyserer et historisk fenomen i relasjon til det omkringliggende samfunn. Om hvordan vi vurderer kildenes verdi og holdbarhet, og om hvordan vi fortolker, dokumenterer og formidler våre funn.

Konklusjonen er gitt: Vi har mye å lære av hverandre, og samspill og samarbeid gir gjerne de beste resultatene (21).

\section{Mere fjell}

Av og til

må noe vare lenge,

ellers mister vi vel vettet snart,

så fort som allting snurrer rundt med oss.

Store trær er fint

og riktig gamle hus er fint,

men enda bedre -

fjell.

Som ikke flytter seg en tomme

om hele verden enn forandres

(og det må den snart),

så står de der

og står og står

så du har noe å legge pannen inntil,

og kjøle deg

og holde i noe fast

RolfJacobsen, 1979 (18)

\section{LITTERATUR:}

1. Schiøtz A. Prostitusjonen i Kristiania ca. 1870-189o. En sosialhistorisk undersøkelse. Hovedoppgave. Oslo: Historisk institutt, Universitetet i Oslo, 1977.

2. Schiøtz A. Prostitusjon og prostituerte i 1880-åras Kristiania. I: Gotaas AM, Gulli B, Melby K, Schiøtz A. Det kriminelle kjønn. Om barnefødsel i dølgsmål, abort og prostitusjon. Bidrag til norsk kvinnehistorie. Oslo: Pax forlag, 1980:35-80.

3. Kaldal I. Frå sosialhistorie til nyare kulturhistorie. Oslo: Samlaget, 2002.

4. Lie AK. Nyere perspektiver innen medisinsk historie. Nytt norsk tidsskrift 2008; 25: 157-68.

5. Schiøtz A. Viljen til liv. Medisin- og helsehistorie frå antikken til vår tid. Oslo: Samlaget, 2017.

6. Dahl LV. Aktstykker vedkommende Prostitutionsvæsenet i Christiania i Aaret 1888. I: Beretning om Folkemængdens og Sundhedstilstanden i Christiania i Aaret 1888. Christiania 1889: 72-116.

7. Huisman F, Warner JH, red. Locating Medical History. The Stories and Their Meanings. Baltimore, 
MD: Johns Hopkins University Press, 2004.

8. Butterfield H. The Whig Interpretation of History. London: Bell, 1931. Reprint New York: W.W Norton Company, 1965.

http://seas3.elte.hu/coursematerial/LojkoMiklos/Butterfield,_The_Whig_Interpretation_of_History.p df(13.9.2017).

9. Johannisson K. At tage pulsen på medicinhistorien - diagnose og prognose. Den jyske historiker 1995; 72 7-15.

10. Biersack A, Hunt L, red. The New cultural History. Essays. Berkeley, CA: California University Press, 1989.

11. Laqueur T. Making Sex. Body and Gender from the Greeks to Freud. Cambridge, MA: Harvard University Press, 1990.

12. Johannisson K. Det mørke kontinentet. Om kvinner, sykelighet og kulturen rundt århundreskiftet. Oslo: Aventura forlag, 1996.

13. Cooter R. «Framing» the End of the Social History of Medicine. I: Huisman F, Warner JH, red. Locating Medical History. The Stories and Their Meanings. Baltimore, MD: Johns Hopkins University Press, 2004:309-37.

14. Fissell ME. Making Meanings from the Margins: The New Cultural History of Medicine. I: Huisman F, Warner JH, red. Locating Medical History. The Stories and Their Meanings. Baltimore, MD: Johns Hopkins University Press, 2004:364-89.

15. Gradmann C. Krankheit im Labor. Robert Koch und die medizinische Bakteriologie. Göttingen: Wallstein Verlag, 2005. Engelsk utg.: Laboratory Disease. Robert Koch's medical Bacteriology. Baltimore, MD: Johns Hopkins University Press, 2009.

16. Kvande L. Bilete av eit svangerskap. Ultralyd-diagnostikk i norsk svangerskapsomsorg 1970-1995. Doktoravhandling. Trondheim: Institutt for tverrfaglege kulturstudiar, Norges teknisknaturvitenskapelige universitet, 2008.

17. Reverby S. «Normal Exposure» and Inoculation Syphilis: A PHS «Tuskegee» Doctor in Guatemala, 1946-48. J Policy Hist 2011; 23: 6 - 28. [CrossRef]

18. Jacobsen R. Mere fjell (utdrag). I: Tenk på noe annet, Oslo: Gyldendal, 1979.

19. Slagstad K. Fortelling som kritikk. Tidsskr Nor Legeforen 2017; 137: 1333 - 40. [CrossRef]

20. Horton R. Offline: The moribund body of medical history. Lancet 2014;384: 292. [CrossRef]

21. Schiøtz A. Om å se seg selv i en sammenheng - medisin og historie - de to kulturer. Tidsskr Nor Lægeforen 2000; 120:3746 - 8. [PubMed]

22. McKeown T. The Origins of Human Disease. Oxford: Basil Blackwell, 1988.

Publisert: 12. desember 2017. Tidsskr Nor Legeforen. DOI: 10.4045/tidsskr.17.0891

Mottatt 13.10.2017, godkjent 20.10.2017.

(C) Tidsskrift for Den norske legeforening 2020. Lastet ned fra tidsskriftet.no 